\title{
New Strategy for Managing Damping-off and Root Rot Disease of Cucumber Caused by Rhizoctonia solani by Seed Soaking in Formula of Antioxidant with Micronutrients
}

\author{
Safaa Ahmed Yousef ${ }^{1 *}$, Mohammad Magdy El-Metwally², Sami A Gabr ${ }^{3,4}$ and Ahmad H Al-Ghadir ${ }^{4,5}$ \\ ${ }^{1}$ Plant Pathology Research Institute, Agricultural Research Center, Giza, Egypt \\ ${ }^{2}$ Department of Botany and microbiology, Faculty of Science, Damanhour University, Egypt \\ ${ }^{3}$ Department of Anatomy, Faculty of Medicine, Mansoura University, Mansoura, Egypt \\ ${ }^{4}$ Rehabilitation Research Chair (RRC), King Saud University, Riyadh, Saudi Arabia \\ ${ }^{5}$ Department of Rehabilitation Science, College of Applied Medical Sciences, King Saud University, Riyadh, Saudi Arabia
}

\begin{abstract}
Cucumber is one of many susceptible crops to damping-off and root rot disease caused by Rhizoctonia solani. Sclerotia of $R$. solani can be remain viable in soil for several years as important source of primary infection, In our laboratory trails, The soaking of $R$. solani sclerotia in Potassium tartarate as antioxidant and a mixture of micronutrients for $48 \mathrm{~h}$ showed a great reduction in colony diameter reach to $52 \%$ with complete inhibition of sclerotia formation after $24 \mathrm{~d}$ of incubation. For more investigation, the treated sclerotia examined under SEM which showed germ hyphae alterations, includes, changes in measurements of hyphae, increased branches, reduce length of branches, retardation of the plasmolemma and collapse of cytoplasm.

By application of this formula in greenhouse, the seedling stands up increased by $46.4 \%$ on day 6 and $60.9 \%$ respectively on day 14 over check ones. In addition to seedlings protection, treatments also improve plant height, fresh weight of shoot and root with clear increase in total phenol contents. In field experiment highest fruit production as well as increase in nitrogen, phosphor, potassium and protein content of fruits. This information sheds new light on environmental factors that influence plant-pathogen interactions, and may be applied to develop a management strategy for $R$. solani control based on host nutrition.
\end{abstract}

Keywords: Cucumber; Rhizoctonia solani; Antioxidant; Micronutrients

\section{Introduction}

Rhizoctonia solani (teleomorph: Thanatephorus cucumeris) is one of common disease throughout the world as well as the most economically important root diseases of cucumber with broad host range that includes most annual and many perennial plants. Generally, Rhizoctonia survives between crops as sclerotia or as fungal mycelia in the soil. Young plants are more susceptible to infection than older plants. Application of the fungicides pollutes the environment, leave harmful residues and can lead to the development of resistant strains of the pathogen [1]. Use of nutrients and micronutrients i.e. pre planting treatment is alternative methods which reduce fungicides usage.

Nutrients are important for growth and development of plants and also microorganisms, and they are important factors in disease control [2]. Additionally, micronutrients are considered very important factors to protect the plants against adverse environmental conditions [3].

Microelements plays a key role in controlling (scavenging) both generation and detoxification of free oxygen radicals in which that lead to potentially prevention of their adverse consequences, i.e. damaging of membrane lipids [4].

Recently groups of substances known as antioxidants or oxygen free radical scavengers were exogenously applied to protect against adverse effects of environmental oxidative stress, such as mineral nutrients [5].

Several reports show that the antioxidants may control soil-borne fungal diseases [6], as well as the antioxidants enhance the level of plant phenols which play a major role in plant disease defence, growth and development.

The objective of this work is study the role of seed treatment by formula of potassium tartarate, and micronutrients on managing $R$. solani of cucumber with special reference the yield and fruit quality.

\section{Material and Methods}

The type and concentration of antioxidant and micronutrients used in this study are based on previous unpublished study.

\section{Isolation of pathogenic fungus}

R. solani were isolated from naturally infected cucumber seedling, showing damping-off and root rot symptoms. The isolated fungus identified on the basis of cultural and microscopic morphological characters according to the key given by Booth [7]. Pathogenicity of isolated fungus toward cucumber plants (cv. Beit Alpha) was estimated according to Sallam et al. [8]. Artificial inoculum of pathogenic fungus was prepared by growing fungus on sorghum-sand medium as described by Abd El-Khair and El-Mougy [9]. The most aggressive

*Corresponding author: Safaa Ahmed Yousef, Plant Pathology Research Institute, Agricultural Research Center, Giza, Egypt, E-mail: Safaaphd3@yahoo.com

Received July 07, 2013; Accepted September 06, 2013; Published September 12,2013

Citation: Safaa AY, El-Metwally MM, Gabr SA, Al-Ghadir AH, (2013) New Strategy for Managing Damping-off and Root Rot Disease of Cucumber Caused by Rhizoctonia solani by Seed Soaking in Formula of Antioxidant with Micronutrients J Plant Pathol Microb 4: 196 doi:10.4172/2157-7471.1000196

Copyright: ( 2013 Safaa AY, et al. This is an open-access article distributed unde the terms of the Creative Commons Attribution License, which permits unrestricted use, distribution, and reproduction in any medium, provided the original author and source are credited. 
Citation: Safaa AY, El-Metwally MM, Gabr SA, Al-Ghadir AH, (2013) New Strategy for Managing Damping-off and Root Rot Disease of Cucumber Caused by Rhizoctonia solani by Seed Soaking in Formula of Antioxidant with Micronutrients. J Plant Pathol Microb 4: 196 doi:10.4172/21577471.1000196

isolate of pathogenic fungus was used in vitro and in pot experiments.

\section{Sclerotia collection}

From $14 \mathrm{~d}$ old culture of R. solani, The sclerotia were collected by sterile needle and surface sterilized by $5 \%$ (sodium hypochlorite) for 5 min. then washed thoroughly with sterilized distilled water.

\section{Vitro experiments}

Effect of $\mathrm{K}$ tartarate and micronutrients or their combinations on the mycelial growth of $\boldsymbol{R}$. solani: These mixture were selected as a result from unpublished previous study. The antioxidant Potassium tartarate $(5 \mathrm{mM})$ or the micronutrients mixture which consists of ( $\mathrm{Zn}$ sulfate, $500 \mathrm{ppm}$; Mn sulfate, $500 \mathrm{ppm}$; Cu sulfate, $100 \mathrm{ppm}$; Boric acid, $100 \mathrm{ppm}$ and Selenium $1.0 \mathrm{ppm}$ ) or the both were tested for their effects on the mycelial growth of $R$. solani. The check and tested Petri-dishes containing Czapek's agar medium (three replicate dishes per concentration of a chemical) were inoculated in the centre with a mycelial disc (4-mm diameter) taken from the periphery of actively growing colonies of $R$. solani. All Plates were incubated in dark at $25 \pm$ $2^{\circ} \mathrm{C}$. The diameter of each colony was measured after 4 days.

Effect of soaking $R$. solani sclerotia in antioxidant with micronutrients formula on sclerotial germination and formation of new sclerotia: The sclerotia were soaked for 24 and $48 \mathrm{~h}$ in formula of Potassium tartarate with the micronutrients mixture before planting it in each plate. The plates were incubated at $25 \pm 2^{\circ} \mathrm{C}$ on Czapek's agar medium and the diameter of fungal colonies was recorded daily till the plates in any treatment were filled by the fungal growth. Numbers of new sclerotia in each treatment were also recorded until 24 days.

\section{Scanning electron microscope (SEM)}

The tested sclerotia fixed it in buffered aldehyde for 3 hours, post fixing it in osmium tetroxide for 1 hour, Dehydrate by a graded ethanol series $25 \%, 50 \%, 75 \%$, and two $100 \%$ each for $10 \mathrm{~min}$. $(5 \times 10=50 \mathrm{~min})$ and finally coat with gold and view in JSM-6380 LA scanning electron microscope.

\section{Pots experiment}

Seeds of the cultivar cv. Beit Alpha, susceptible to R. solani were soaking for 12 hours in: a) Tap water (control); b) Potassium tartarate; $c$ ) micronutrients mixture and d) Potassium tartarate plus micronutrients mixture. The first set was infested pots $(25 \mathrm{~cm}$ in diameter $)$ with virulent isolate of $R$. solani at the rate of $2 \%$ of the soil weight was used as control. Seeds were sown in the prepared pots (five seeds per pot). Three pots were employed for each treatment. In each treatment, the number of seedlings that emerged in each pot was recorded 6 days after sowing. Seedling stands gave an estimate of pre-emergence dampingoff in infested pots. A second observation on seedling stands 14 days after sowing estimated the total disease. The effect on percentage seed germination and rate of seedling emergence recorded in no infested pots. At flowering stage three plants from each pot were chosen to determine growth characters plant height, fresh weight of shoot and root.

\section{Biochemical changes in response to infection}

Estimation of total phenols: Changes in total phenols were determined after two, four and six days from soil infestation.

In seedling stage, fresh infested roots of cucumber seedlings were used. Total phenolic content (TPC) was determined as per Singh et al. [10]. Samples of $2 \mathrm{~g}$ were homogenized in $80 \%$ aqueous ethanol at room temperature and centrifuged at $10000 \mathrm{rpm}$ for $15 \mathrm{~min}$. under cooling and the supernatants were saved. The residues were extracted in $80 \%$ ethanol. The supernatants were taken and evaporated to dryness at room temperature. Residues were dissolved in $5 \mathrm{~mL}$ distilled water. One hundred microliters of each extract was water diluted to $3 \mathrm{~mL}$. The 0.5 $\mathrm{mL}$ of Folin-Ciocalteau reagent was added. After $3 \mathrm{~min}, 2 \mathrm{~mL}$ of $20 \%$ of sodium carbonate was mixed thoroughly to the extract. The developed color was spectrophotometrically measured at $650 \mathrm{~nm}$. After $60 \mathrm{~min}$, while catechol was used as a standard. The results were expressed as mg catechol/100 $\mathrm{g}$ fresh weight.

Field plots trials: Field trials were designed to study the effect of selected formulation of antioxidant with micronutrients on the vigor of cucumber plants, quality and quantity of the fruits. Also, to verify the results obtained from pots experiments. The trials were conducted at the experimental farm, Plant Pathology Department, Faculty of Agriculture, Mansoura University.

Cucumber seeds were soaked before sowing for $12 \mathrm{~h}$ in tap water as a control, in Potassium tartarate as antioxidant in mixture of micronutrients alone and in mixture of potassium tartarate and micronutrients:

A completely randomized block design experiment with three replicates was used for confirming the results in vivo. Each row was 130 $\mathrm{cm}$ length, $80 \mathrm{~cm}$ width and the space between plants was $25 \mathrm{~cm}$. The recommended cultural practices for growing cucumber were performed according to previously experiments. Agricultural sulphur applied to the soil before week from sowing at the half dose recommended, whereas phosphorus divided into two portions. One was mixed with the top layer of the soil with sowing and the second was added after completely germination. The amounts of each fertilizer required for each plot were calculated on the basis of the ratio between area of plot and feddan. The nitrogen and potassium fertilizers were divided into four portions. Each portion was added to the soil with sowing seeds and after 15, 30 and 45 days from sowing.

Daily observations of seedlings and follow up emergence of symptoms damping-off and rotted seedlings naturally as well as healthy cucumber plants were recorded.

Yield and its component: Cucumber fruits at premature stage were picked at the mid harvesting season (60 days after sowing), then weighted and the following data were calculated.

Fruit samples of 5 fruits from each experimental plot were taken to determine average fruit weight (gm), total yield/1 $\mathrm{m}^{2}$ and chemical analysis of fruits. A fresh portion of a fruits was used for the estimation of biochemical properties such as total phenol, the remainder portion was dried at $100^{\circ} \mathrm{C}$, powdered and used for estimation of percentage of protein and minerals (nitrogen, phosphorus and potassium). Estimated in soil department, Faculty of Agriculture, Mansoura University.

\section{Statistical analysis}

Data were analyzed with the statistical analysis software, CoStat V6.4. Data were first subjected to analysis of variance (ANOVA). Comparisons among means were made using least significant differences (L.S.D.) at $\mathrm{P} \leq 0.05$.

\section{Results}

Effect of soaking $R$. solani sclerotia in mixture of Potassium tartarate (A) and micronutrients formula (Mix) in colony diameter and formation of new sclerotia

Soaking of $R$. solani sclerotia in combination of potassium tartarate 
Citation: Safaa AY, El-Metwally MM, Gabr SA, Al-Ghadir AH, (2013) New Strategy for Managing Damping-off and Root Rot Disease of Cucumber Caused by Rhizoctonia solani by Seed Soaking in Formula of Antioxidant with Micronutrients. J Plant Pathol Microb 4: 196 doi:10.4172/21577471.1000196

and micronutrients have a great effect in the growth and reformation of $R$. solani sclerotia. As shown Table 1, the colony diameter of fungus sclerotia which soaked for $24 \mathrm{~h}$, inhibited by 72,14 and $5 \%$ after one, two and five days respectively and formed new sclerotia after 7 days as control where the $48 \mathrm{~h}$ soaked sclerotia showed more colony diameter inhibition with 72,65 and $52 \%$ respectively, moreover it cannot formed sclerotia after 24 days of incubation.

Examination of control and treated sclerotia under scaning electron microscope (SEM): For more investigation, the treated and untreated sclerotia examined under SEM which revealed that, the untreated sclerotia showed normal germ hyphae in its shape and size where the $48 \mathrm{~h}$ treated ones showed germ hyphae alterations, includes, changes in measurements of hyphae, increased branches, reduce length of branches, retardation of the plasmolemma and collapse of cytoplasm (Figures 1 and 2).

Pots experiment: Effect of Potassium tartarate and/or micronutrients in Cucumber damping-off and root rot disease caused by $R$. solani. Data in Table 2 indicate that, seedling stand percentage of cucumber plants after 6 and $14 \mathrm{~d}$ from sowing were decreased due

\begin{tabular}{|c|c|c|c|c|c|}
\hline \multicolumn{7}{|c|}{ Colony diameter (cm) } \\
\hline Incubation time & Control & \multicolumn{2}{|c|}{ Soaked for 24 } & \multicolumn{2}{c|}{ Soaked for 48 } \\
\hline & $\begin{array}{c}\text { \% of } \\
\text { inhibition }\end{array}$ & $\begin{array}{c}\text { Colony } \\
\text { diameter }\end{array}$ & $\begin{array}{c}\% \text { of } \\
\text { inhibition }\end{array}$ & $\begin{array}{c}\text { Colony } \\
\text { diameter }\end{array}$ \\
\hline one day & $1.8 f^{*}$ & $72 \mathrm{a}$ & $0.5 \mathrm{~h}$ & $72 \mathrm{a}$ & $0.5 \mathrm{~h}$ \\
\hline two days & $3.5 \mathrm{~d}$ & $14 \mathrm{~d}$ & $3 \mathrm{be}$ & $65 \mathrm{~b}$ & $1.2 \mathrm{~g}$ \\
\hline five days & $09: 00 \mathrm{AM}$ & $5 \mathrm{e}$ & $8.5 \mathrm{~b}$ & $52 \mathrm{c}$ & $4.3 \mathrm{c}$ \\
\hline $\begin{array}{c}\text { formation of new } \\
\text { sclerotia }\end{array}$ & $\begin{array}{c}\text { formed a } \\
\text { sclerotia after } \\
7 \mathrm{~d} \text { of } \\
\text { incubation }\end{array}$ & $\begin{array}{c}\text { formed a sclerotia } \\
\text { after 7d of } \\
\text { incubation }\end{array}$ & \multicolumn{2}{|c|}{$\begin{array}{c}\text { Not Formed a sclerotia } \\
\text { after 24d }\end{array}$} \\
\hline
\end{tabular}

Table 1: Effect of soaking $R$. solani sclerotia in Potassium tartarate and micronutrients mixture combination in colony diameter and formation of new sclerotia.
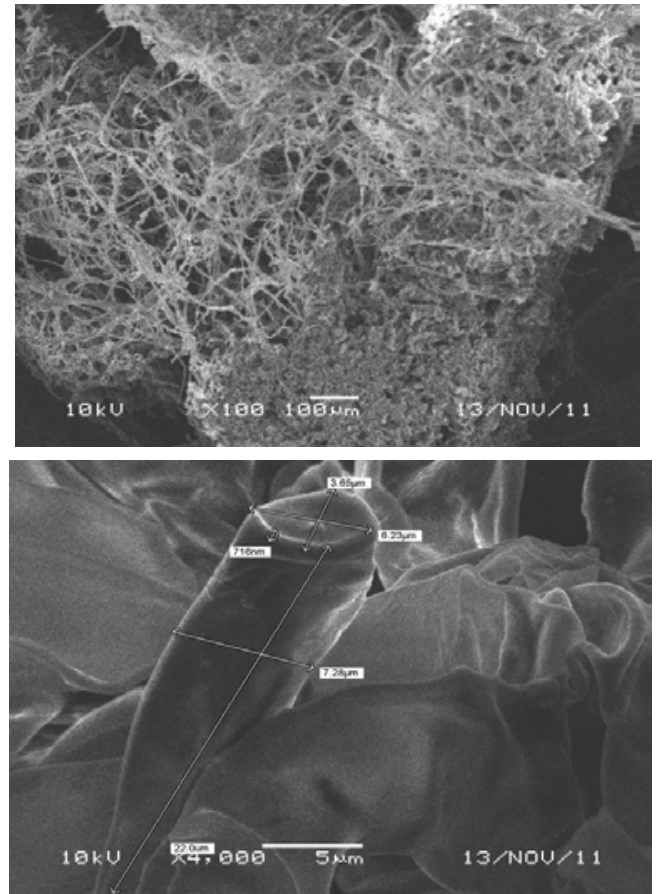

Figure 1: Untreated (control) sclerotia.
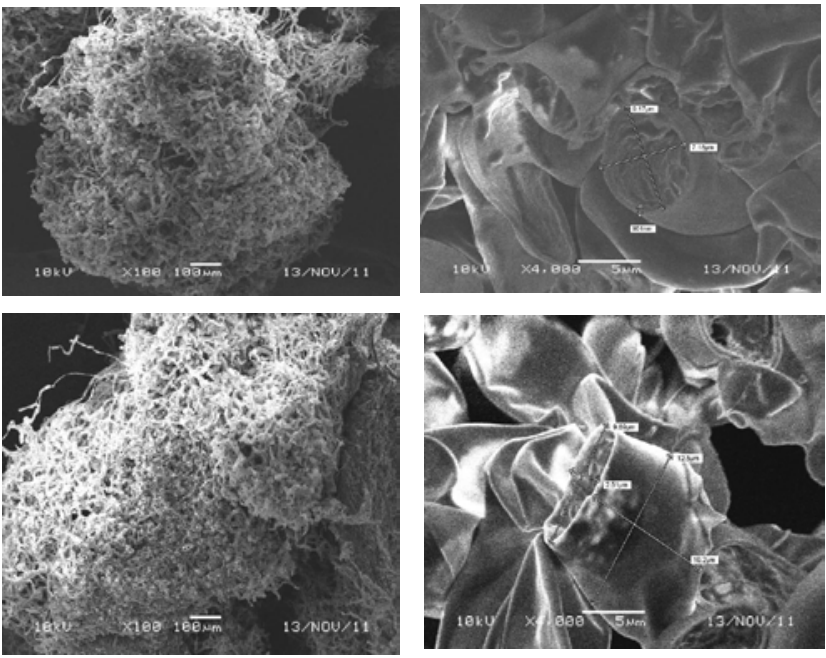

Figure 2: Sclerotia treated for $48 \mathrm{~h}$ by combination of antioxidant, potassium tartarate, and micronutrients.

\begin{tabular}{|c|c|c|c|c|}
\hline \multirow{2}{*}{} & \multicolumn{2}{|c|}{ After 6 days } & \multicolumn{2}{c|}{ After 14 days } \\
\cline { 2 - 5 } & infested & Non-infested & infested & Non-infested \\
\hline Check & $56 \mathrm{~g}$ & $70 \mathrm{e}$ & $46 \mathrm{f}$ & $73 \mathrm{~d}$ \\
\hline $\begin{array}{c}\text { Potassium } \\
\text { tartarate (A) }\end{array}$ & $79.9(42.7)^{\star} \mathrm{d}$ & $93(32.9) \mathrm{a}$ & $73(58.7) \mathrm{d}$ & $97(32.9) \mathrm{a}$ \\
\hline $\begin{array}{c}\text { Micronutrients } \\
\text { mixture (Mix) }\end{array}$ & $66.7(50.9) \mathrm{f}$ & $86.6(23.7) \mathrm{b}$ & $59(28.3) \mathrm{e}$ & $87.6(20) \mathrm{b}$ \\
\hline (A)+Mix & $82(46.4) \mathrm{c}$ & $94(34.2) \mathrm{a}$ & $74(60.9) \mathrm{c}$ & $97(32.9) \mathrm{a}$ \\
\hline
\end{tabular}

*Percentage of increase over check

Table 2: Seedling stands (\%) of cucumber in soil infested with $R$. solani and resulted from seed treatment by Potassium tartarate and/or micronutrients.

\begin{tabular}{|c|c|c|c|c|c|c|}
\hline \multirow[t]{2}{*}{ Treatments } & \multicolumn{3}{|l|}{ Infested } & \multicolumn{3}{|c|}{ Non-infested } \\
\hline & $\begin{array}{l}\text { Length } \\
\text { (cm) }\end{array}$ & $\begin{array}{l}\text { Fresh } \\
\text { weight/ } \\
\text { shoot (g) }\end{array}$ & $\begin{array}{l}\text { Fresh } \\
\text { weight/root } \\
\text { (g) }\end{array}$ & $\begin{array}{l}\text { Length } \\
\text { (cm) }\end{array}$ & $\begin{array}{l}\text { Fresh } \\
\text { weight/ } \\
\text { shoot (g) }\end{array}$ & $\begin{array}{l}\text { Fresh } \\
\text { weight/root } \\
\text { (g) }\end{array}$ \\
\hline Check & 21.0d & $9.18 \mathrm{~g}$ & $0.35 f$ & $27.6 c$ & $17.6 \mathrm{c}$ & $0.7 c$ \\
\hline (A) & $\begin{array}{l}28.3 \\
(34.8)^{*} \mathrm{C}\end{array}$ & $\begin{array}{l}12.40 \\
(35.1) f\end{array}$ & $\begin{array}{l}0.50 \\
(42.9) \mathrm{e}\end{array}$ & $\begin{array}{l}33.0 \\
(19.6) \mathrm{b}\end{array}$ & $\begin{array}{l}19.3 \\
(9.7) \mathrm{b}\end{array}$ & $\begin{array}{l}0.8 \\
(14.2) \mathrm{b}\end{array}$ \\
\hline Mix & $\begin{array}{l}31.7 \\
(50.1) \mathrm{b}\end{array}$ & $\begin{array}{l}12.5 \\
(36.2) f\end{array}$ & \begin{tabular}{|l}
0.63 \\
$(80.0) d$
\end{tabular} & $\begin{array}{l}33.0 \\
(19.6) \mathrm{b}\end{array}$ & $\begin{array}{l}15.4 \\
(-12.5) d\end{array}$ & $\begin{array}{l}0.8 \\
(14.3) \mathrm{b}\end{array}$ \\
\hline$(A)+\operatorname{Mix}$ & $\begin{array}{l}31.7 \\
(50.1) \mathrm{b}\end{array}$ & $\begin{array}{l}13.3 \\
(44.9) \mathrm{e}\end{array}$ & $\begin{array}{l}0.67 \\
(91.4) d\end{array}$ & $\begin{array}{l}36.0 \\
(30.4) a\end{array}$ & $\begin{array}{l}20.4 \\
(15.9) a\end{array}$ & $\begin{array}{l}1.2 \\
(71.4) a\end{array}$ \\
\hline
\end{tabular}

Table 3: Effect of seed treatments by Potassium tartarate and/or micronutrients on cucumber vegetative growth parameters under greenhouse conditions in infested and non-infested pots with $R$. solani.

to soil infestation with $R$. solani. On the other hand, seed presoaking in Potassium tartarate alone or with micronutrients combination gave highly significant protection of cucumber seedlings against dampingoff and root rot. The data revealed that seedling stands up increased by $42.7 \%$ \& $46.4 \%$ respectively on day 6 and $58.7 \& 60.9 \%$ respectively on day 14 over check ones. Moreover, seedling growth was better in no infested pots with seed treatment by potassium tartarate and micronutrients mixture.

\section{The effect of Potassium tartarate and/or micronutrients on growth characters in relation with $R$. solani infection}

Data in Table 3 show negative relationship between infection with $R$. solani and vegetative characters of cucumber plants. However, cucumber seed soaking treatments was significantly improved plant 
Citation: Safaa AY, El-Metwally MM, Gabr SA, Al-Ghadir AH, (2013) New Strategy for Managing Damping-off and Root Rot Disease of Cucumber Caused by Rhizoctonia solani by Seed Soaking in Formula of Antioxidant with Micronutrients. J Plant Pathol Microb 4: 196 doi:10.4172/21577471.1000196

growth parameters (plant height, plant fresh and root weight) which grown in non infested and infested pots with $R$. solani.

Phenol content: Total phenols were estimated in roots of infested seedlings of two, four and six days after seedlings inoculation with $R$. solani in soil pots. Data in Table 4 show that total phenols in fresh roots of cucumber steeply raised in seeds treated with the potassium tartarate after two days by $155.8 \%$ over the check where the combination of Potassium tartarate with micronutrients mixture recorded its highest effect in total phenol increase by $93.4 \%$ increase over check after 4 $\mathrm{d}$. In the other hand micronutrients mixture alone recorded higher total phenols content compared with other treatment when estimated tow, four and six days after inoculation especially after four days of inoculation. On the other hand the same previous treatment showed lowest concentration in total phenols content when estimated six days after inoculation.

Field trial: According to the previous results obtained from the pot experiments, the field experiments were designed by selecting some of the applied treatments to focus on their effects on natural infection by $R$. solani damping-off disease and improving cucumber growth and yield quality.

\section{Effect of combination of Potassium tartarate and/or micronutrients in total yield and Concentration of protein and minerals $(\mathrm{N}, \mathrm{P} \& \mathrm{~K})$ in cucumber fruits in field trials}

Total fruit yield were highest by all seed treatments when comparisons with the untreated check (Table 5). The highest fruit production was obtained with potassium tartarate followed by its mixture with micronutrients giving increase in total yield by (130.5\% and $73.5 \%$, respectively) as well as increase in nitrogen and protein content of the fruit by $117 \%$ over check. In the other hand micronutrients revealed the lowest percentage increase in NPK and protein compared to other treatments, while the same treatment was highest comparisons with the untreated check.

\section{Discussion}

The control of plant diseases using classical pesticides raises serious concerns about food safety, environmental quality and pesticide resistance, which have dictated the need for alternative pest management

\begin{tabular}{|l|l|l|l|}
\hline \multirow{2}{*}{ Treatments } & \multicolumn{3}{l|}{ Total phenols $(\mathbf{m g} / 100 \mathrm{~g}$ fresh weight of roots) after } \\
\cline { 2 - 4 } & 2d & $4 \mathrm{~d}$ & $6 \mathrm{~d}$ \\
\hline Check & $27.3 \mathrm{j}$ & $15.22 \mathrm{i}$ & $22.97 \mathrm{k}$ \\
\hline (A) & 69.85 & 27.51 & 30.72 \\
& $(155.8)^{*} \mathrm{C}$ & $(80.7) \mathrm{j}$ & $(33.7) \mathrm{g}$ \\
\hline Mix & 70.65 & 97.64 & 55.43 \\
& $(158.7) \mathrm{b}$ & $(542.3) \mathrm{a}$ & $(141.2) \mathrm{d}$ \\
\hline (A)+Mix & $31.31(14.6) \mathrm{f}$ & $29.45(93.4) \mathrm{h}$ & $33.92(47.6) \mathrm{e}$ \\
\hline
\end{tabular}

Table 4: Total phenols in roots of diseased cucumber seedlings resulted from seeds treated with potassium tartarate, micronutrients and their combinations after inoculation with $R$. solani in soil pots.

\begin{tabular}{|l|c|c|c|c|c|}
\hline Treatments & $\begin{array}{c}\text { Total yield } / \\
\mathbf{m}^{\mathbf{2}} \mathbf{( g )}\end{array}$ & $\mathbf{\% N}$ & $\% \mathbf{P}$ & $\% \mathbf{K}$ & \%Protein \\
\hline Check & $619.3 \mathrm{~d}$ & $0.98 \mathrm{~d}$ & $0.17 \mathrm{~b}$ & $2.65 \mathrm{c}$ & $6.13 \mathrm{c}$ \\
\hline (A) & $\begin{array}{c}1427 \\
(130.5)^{\star} \mathrm{a}\end{array}$ & $\begin{array}{c}2.13 \\
(117.3) \mathrm{a}\end{array}$ & $\begin{array}{c}0.22 \\
(77.3) \mathrm{a}\end{array}$ & $\begin{array}{c}3.32 \\
(25.3) \mathrm{b}\end{array}$ & $\begin{array}{c}13.31 \\
(117.1) \mathrm{a}\end{array}$ \\
\hline Mix & $973(57.1) \mathrm{c}$ & $1.205(22.4) \mathrm{c}$ & $0.173 \mathrm{~b}$ & $2.8(5.6) \mathrm{c}$ & $7.52(22.9) \mathrm{bc}$ \\
\hline (A)+Mix & $1074(73.5) \mathrm{b}$ & $1.54(57.1) \mathrm{b}$ & $0.18(5.9) \mathrm{b}$ & $3.94(48.7) \mathrm{a}$ & $9.63(57.1) \mathrm{b}$ \\
\hline
\end{tabular}

Table 5: Percentage of N P K and protein in Cucumber fruits of treated and untreated seeds in field trial. techniques. In particular, nutrients could affect the disease tolerance or resistance of plants to pathogens.

In vitro studies on linear growth and sclerotia germination show that the innovated formulation prepared by the author may acts as antifungal formulation. Antioxidant alone or in combination with micronutrients in vitro may inhibit a number of enzymes by dissolving the membrane lipids and interfere with membrane functions, including transport of nutrients. Also interfere with the synthesis of protein, RNA and DNA, and destroy the membrane potential similar to other weak organic acids [11].

Another explanation based on the applied mixture can inhibit the activity of enzymes involved in the biosynthesis of melanin ( 1 , 8-dihydroxynaphthalene, DHN) in a wide range of plant pathogenic fungi [12], which is required in initiation and developmental stages of sclerotia formation, and was maintained at high levels after the initiation stage. Moreover the entering of undifferentiated mycelium of $R$. solani to differentiated state accompanied by a decrease in the low oxidative stress-associated total reduced thiols and/or by an increase of the high oxidative stress-associated total oxidized thiols either in the sclerotial mycelial substrate or in its corresponding sclerotia, this formula may also affected the thiol redox state [13].

Manganese plays a role in regulating the levels of auxin in plant tissues by activating photosynthesis especially photosystem two [14]. Auxin may induced the systemic resistance and encourage the meristemic activity of the plant which resulted in more cell division and cell enlargement [15]. Nutrition influences all of the interacting components affecting disease severity. Plants contain preformed anti-microbial compounds and have active response mechanisms where inhibitory phytoalexins, phenols, flavonoids, and other defense compounds accumulate around infection sites of resistant plants if the nutrients required for the synthesis or induction of those compounds are adequate [16]

Manganese and zinc are co-factors of Super Oxide Dismutase (SOD), which considered enzymatic antioxidant, hence alleviate the harmful effect of Reactive Oxygen Species (ROS free radicals) caused by fungal stress. These findings are in agreement with Kostas and Christos [17], they found that the foliar application of microelements can be used to reduce the severity of tanspot disease on durum wheat, however the physiological basis of this pattern still unknown.

Primed seeds may have avoided Rhizoctonia by rabidly growing through the susceptibility seedling stage. Antioxidant successfully protected cucumber seedlings from pre-emergence damping-off and post-emergence seedling mortality caused by a virulent isolate of $R$. solani this antioxidant did not reduce colony growth of $R$. solani in vitro. Therefore, it is suggested that some inducible defense mechanisms in cucumber seedlings tissues, rather than a direct antifungal action against $R$. solani. Results presented here clearly show that mixture of antioxidant with micronutrients have the potential to induce systemic resistance in cucumber plants. They were applied as seed treatment at fairly low concentrations. Several reports showed that such micronutrients cause systemic protection most possibly through induced changes in host metabolism. The reports also show that $\mathrm{Mn}$ can control a number of diseases as $\mathrm{Mn}$ has an important role in lignin biosynthesis, phenol biosynthesis, photosynthesis and several diseases reduction is most often attributed to improved nutrition that boosts host defenses or to direct inhibition of fungal growth and activity [18]. In most cases, the minerals work by directly reducing the inoculum potential, improving host tolerance, or both [19]. The formulation treatment showed a 
Citation: Safaa AY, El-Metwally MM, Gabr SA, Al-Ghadir AH, (2013) New Strategy for Managing Damping-off and Root Rot Disease of Cucumber Caused by Rhizoctonia solani by Seed Soaking in Formula of Antioxidant with Micronutrients. J Plant Pathol Microb 4: 196 doi:10.4172/21577471.1000196

significantly effect in reducing Rhizoctonia damping-off. This effect may due to the enhancement of phenol production in host tissues. This results are in agreement with Morandi et al. [20], Metraux and Raskin [21] who emphasized that phenolic phytoalexin may involved in the resistance of plant to pathogenic microbial infection.

The obtained data also show that all treatments had significant effects on total phenols in fruits. This promotive effect on fruit quality could potentially benefit human health. The result is in agreement with Hanson et al. [22] who indicated that phenols are closely associated with antioxidant activity and suggests that phenolics make a major contribution to antioxidant activity in vegetables fruits.

This stimulatory effect of the combination treatment used in this investigation may also be due to their action as antioxidants which protect the chloroplasts from the production of toxic free radicals, thereby prevent degradation of pigments and inhibit the photo oxidation of pigments that arise under stressful conditions [23].

Pathogenesis by R. solani is characterized by severe damage or death of host cells before or immediately after penetration, and colonization is primarily a process of hyphal growth into moribund tissue. There is evidence of cell wall degrading enzyme activity prior to penetration, and damage to cell membranes and degenerative changes in cytoplasm (oxidative damage by free radicals) can also be detected in cortical cells prior to colonization [24]. Positive effects of this formulation in disease control against damping-off providing another evidence that free radicals are possibly involved in infection and rotting of young seedlings by $R$. solani.

This simple, save and low cost formula can be considered as a clean means of disease control against $R$. solani which can be applied instead of the traditional toxic fungicides that lead to environmental pollution. According to this study using of potassium tartarate and micronutrients mixture in seed treatment not only recognized as an economic factor but also a significant potential for integrating plant nutrition in the management of diseases.

\section{Acknowledgements}

The Authors extend their appreciation to the Deanship of Scientific Research at King Saud University for funding the work through the research group project NO. RGP-VPP-209.

\section{References}

1. Vinale FK, Sivasithamparam EL, Ghisalberti R, Marra SL, Lorito M (2008) Trichoderma-plant-pathogen interactions. Soil Biology and Biochemistry 40: $1-10$.

2. Agrios NG (2005) Plant Pathology. (5thedn), Elsevier, Amsterdam 635

3. El-Sweify AHH, Abd El-Rasoul SHM, Thahar L (2002) Response of flax to irrigation frequency and some micronutrient application in calcareous soils. $J$ Agric Sci Mansoura Univ 27: 7979-7992.

4. Marschner H (1995) Mineral Nutrition of Higher Plants. (2ndedn), Academic London, UK.

5. Wanas AL (2006) Response of squash plants grown in winter season to some natural extract and antioxidants. Ann Agric Sci Moshtohor 40: 83-102.

6. Dmitriev A, Tena M, Jorrin J (2003) Systemic acquired resistance in sunflower (Helianthus annuus L.). Tsitol Genet 37: 9-15.

7. Booth C (1985) The Genus Fusarium. Kew, Surrey. (2ndedn), Commonwealth Mycol Inst 237
8. Sallam MN, Nashwa KA, Abo-Elyousr M, Hassan MAE (2008) Evaluation of Trichoderma species as biocontrol agents for damping off and efficacy of suggested formula. Egypt J Phytopathol 36: 81-93.

9. Abd El- Khair H, Nehal SEM (2003) Field biological approach under organic cultivation conditions for controlling garlic black mould disease infection during storage. Egypt J Appl Sci 18: 50-69.

10. Singh HB, Singh BN, Singh SP, Nautiyal CS (2010) Solid-state cultivation of Trichoderma harzianum NBRI-1055 for modulating natural antioxidants in soybean seed matrix. Bioresour Technol 101: 6444-6453.

11. Eklund T (1989) Organic acids and esters. In mechanisms of action of food preservation procedures, Elsevier Applied Science, New York, USA

12. Butler MJ, Day AW (1998) Fungal melanins: a review. Canadian Journal of Microbiology 44: 1115-1136.

13. Patsoukis D, Georgiou C (2008) Thiol redox state and related enzymes in sclerotium-forming filamentous phytopathogenic fungi. Mycological research 112: 602-610.

14. Marschner H (1986) The Mineral Nutrition of Higher Plants. (1stedn), Academic Press, New York, USA

15. Devlin RM, Witham FH (1983) Plant Physiology. (4thedn), A Division of Wads Worth Inc, Wadads Worth Publishing Co, Belmont, California, USA.

16. Huber DM, Haneklaus S (2007) Managing nutrition to control plant disease. Landbauforschung Volkenrode 57: 313-322.

17. Kostas BS, Christos D (2006) Effect of foliar applied boron, manganese and zinc on tan spot in winter durum wheat. Crop Prod 25: 657-663.

18. Simon A, Sivasithamparam K (1989) Pathogen suppression: A case study in biological suppression of Gaeumannomyces graminis var. tritici in soil. Soil Bio Biochem 21: 331-337.

19. von Broembsen SL, Deacon JW (1997) Calcium Interference with Zoospore Biology and Infectivity of Phytophthora parasitica in Nutrient Irrigation Solutions. Phytopathology 87: 522-528.

20. Morandi D, Branzanti B, Gianinazzi PV (1992) Effect of some plant flavonoids on in vitro behaviour of an arbuscular mycorrhizal fungus. Agonomie 12: 811816

21. Metraux JP, Raskin I (1993) Role of phenolics in plant disease resistance in Biotechnology of Plant Disease Control 191: 209.

22. Hanson PM, Yang RY, Wu J, Chen JT, Ledesma D, et al. (2004) Variation for antioxidant activity and antioxidants in tomato. Journal of the American Society for Horticultural Science 129: 704-711.

23. Sanders D, Pelloux J, Brownlee C, Harper JF (2002) Calcium at the crossroads of signaling. Plant Cell 14 Suppl: S401-S417.

24. Weinhold AR, Sinclair JB (1996) Rhizoctonia solani: penetration, colonization, and host response. In: Sneh B, Jabaji-Hare S, Neate S, Dijst G, (eds.) Rhizoctonia species: Taxonomy, Molecular Biology, Ecology, Pathology and Disease control. Dordrecht, the Netherlands: Kluwer Academic Publishers 16374. 